\title{
Debris flow hazards due to land use changes above source areas in torrent catchments: case study of Les Arcs (Savoie, France)
}

\author{
M. Koscielny ${ }^{1,2}$, R. Cojean ${ }^{1} \&$ I. Thénevin ${ }^{1}$ \\ ${ }^{I}$ Department of Geosciences, \\ Ecole Nationale Supérieure des Mines de Paris, France \\ ${ }^{2}$ Presently: Department of Geotechnic, \\ Conservatoire National des Arts et Métiers de Paris, France
}

\begin{abstract}
For a few decades, land use has changed due to developments in mountainous regions and this has resulted in new pressures on the environment. Consequently, slope instabilities could be a physical expression of such imbalance. Since the 1960s, debris flows events have occurred with an increasing frequency in the Les Arcs catchment area, which have never happened before. At the same time, a large skiing area has been expanding on the upper slopes. The study of climatic series shows that rainfall events linked to debris flow triggering were not especially intense compared to the more extreme precipitations recorded in the area for the past middle century. This observation suggests that additional factors have taken part in the debris flow triggering for the last fifty years. Following this logic, the space-time study of land use has underlined the role of winter sport resort expansion on processes such as runoff and erosion affecting torrent banks and beds, directly at the origin of debris flow generation. A complementary analysis of the effects on hydrology, supported by a hydrological model (PCRaster Software), has also been carried out. According to modelling results, the land use conversion is responsible for a change of annual water balance, resulting in a significant increase of torrent water flow. In particular, these effects are emphasised by the localization of converted surfaces (roads, buildings, car parks, ski runs, sport facilities...) in the catchment recharge areas above steep slopes of torrent channels, where materials are liable to be mobilized. Indeed at this interface, during rainfall events the water flow and especially the peak flow are more intense than in the past, due to water rerouting and concentrating, which may activate erosive processes above debris flow source areas. At the catchment scale, the increasing number of debris flow events seems to be to answer for this change.
\end{abstract}

Keywords: natural hazards, man land use, debris flows, runoff, erosion, hydrological modelling. 


\section{Introduction}

The expression "natural hazard" takes all its sense considering the human point of view. Debris flow triggering conditions and propagation have received attention from numerous authors [1-5], in particular because of their consequences on human life and property. They occur under a critical combination [6-8] of materials availability and water input, generally meaning heavy rainfalls $[9,10]$ on steep slopes. In the mountain region, where conditions are extreme, environmental disturbances (natural or artificial) may activate such processes at short or large time scales. Climatic variability is a natural phenomenon. Its relationship with mass movements, debris flows or floods has been widely studied in recent years [11-14]. In other parts, some of the slope failures $[15,16]$ have been induced by human activities In this paper we have focused our work on the role of the geographical position of land management on small mountainous catchments in debris flow triggering. With this aim we studied the case of the Les Arcs site, an alpine massif that has been occupied by a large ski domain since the $1960 \mathrm{~s}$, in order to understand the increasing occurrence of debris flow events during the last 40 years.

\section{Les Arcs site}

The Massif des Arcs is located on the Bourg-Saint-Maurice area in the Tarentaise Valley in the Northern Alps (fig. 1). It hangs over the Isère torrent on the left bank at a height of over $2000 \mathrm{~m}$. The upper part of the catchment (above $1600 \mathrm{~m}$ ) is transformed into a large ski area with the Arc 1600 and Arc 1800 high capacity resorts.

\section{Review of debris flow events}

The steep slopes of the catchment are drained by seven torrents (fig. 1), the alpine hydrological regime of which is influenced by the snow-pack yield in spring. Considering archives from the Middle Age [17], the first two known debris flow events are dated 1938 but damage was insignificant. In the following years, floods occurred in 1966 in the Ravoire and Eglise torrents, afterwards a series of 26 events of debris flow affected five out of seven streams between 1970 and 2000. The year 1973 was particularly noteworthy for the Ravoire torrent, which triggered height debris flow in the two summer months of August and September. The erosive processes initiated during this period of activity induced favourable conditions for the triggering and the feeding in materials of the 31/03 - 01/04/1981 catastrophic event [14]. During this event, there was a deep scouring of the bed, larger than $20 \mathrm{~m}$ in some stretches. At the Les Arcs catchment scale, this sudden activity has made alterations to the beds and banks and therefore to the morphologic landscape, particularly at elevations of less than $1600 \mathrm{~m}$. Figure 2 represents the chronology of debris flow events for each torrent in terms of their relative position on the massif from NE (Moulins) to SW (Preissaz). 


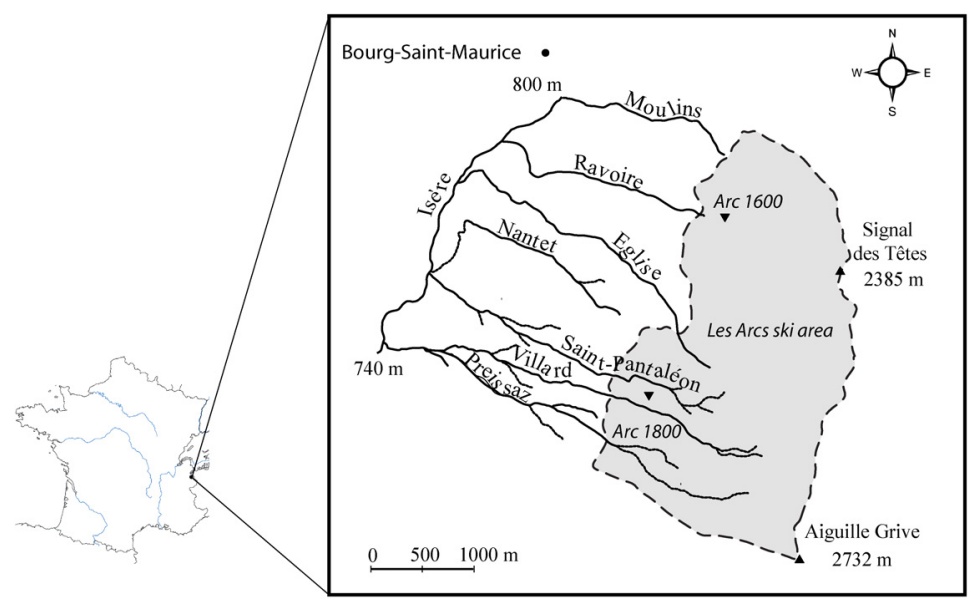

Figure 1: Location map of the Les Arcs site.

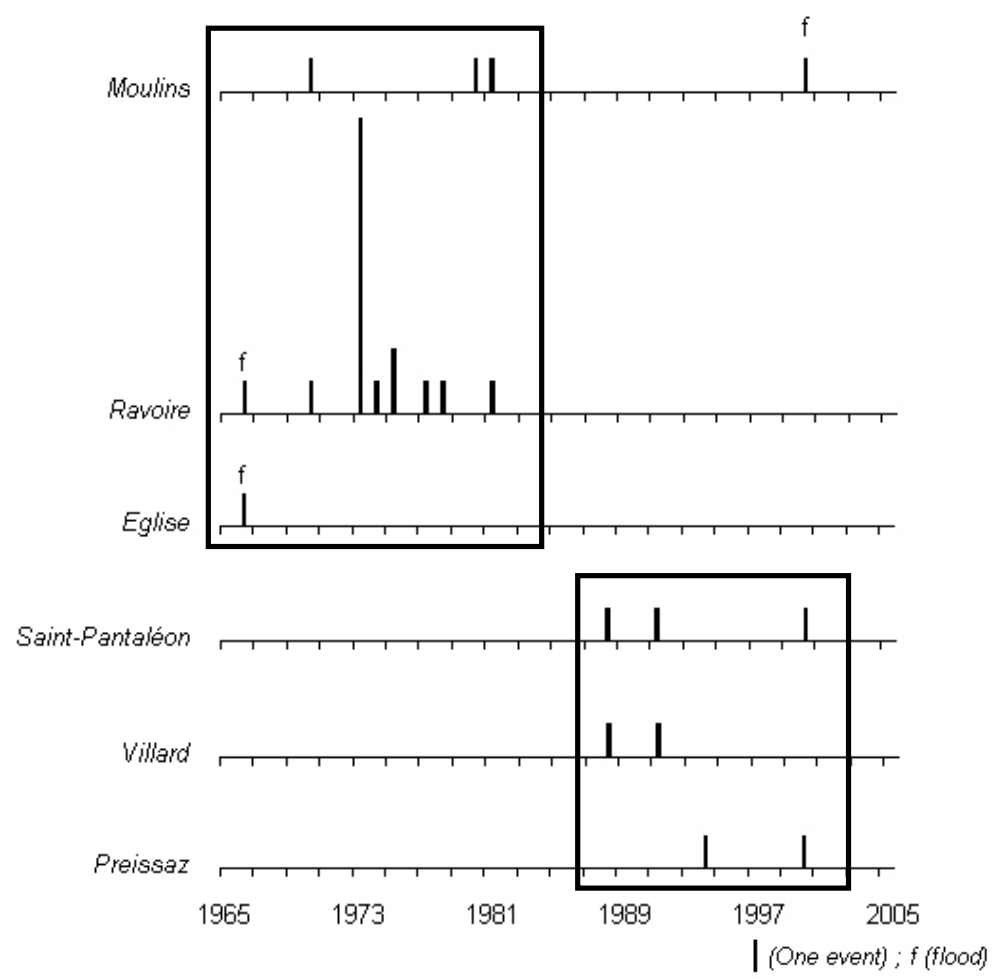

Figure 2: $\quad$ Space-time series of floods and debris flows on the Les Arcs site. 
It shows two consecutive phases of events following this direction. In the early years, from 1970 to 1981, the northern torrents (Moulins, Ravoire) were affected by debris flow. Then, from 1988 to 2000, this hazard concerned the southern ones too (St-Pantaléon, Villard, Preissaz). Such distribution suggests that the triggering factors should have evolved in space and in time during these last 40 years.

\section{Debris flow source areas}

Debris flow needs some particular conditions to be generated: abundant water and materials susceptible to being mobilized on steep slopes constituting source areas. Water quantity depends on hydrometeorological conditions. Materials presence depends on geology and erosive processes. In the Les Arcs catchment, abundant water could be brought by snowmelt in spring or heavy precipitations due to a mountainous climate, which is moreover in evolution [14]. Thus, the geological nature of non-cohesive materials favours erosion. The massif is formed of carboniferous shale bedrock. The actual morphology of the catchment has been formed during the glacial period and the main part of the catchment is covered by morainic deposits and colluviums. This glacial heritage has induced large and local slope movements and slab jointing.

The longitudinal profile of la Ravoire torrent (fig. 3) shows a typical morphology that resulted from the glacial period. In the upper part, the drainage basin presents alternations of glacial benches and steep slopes until the main slope rupture at $1600 \mathrm{~m}$ corresponding to the outset of the torrent thalweg. Below this point, slopes are steeper, and the torrent tends to deeply embank. Debris flow source areas can be localized in this part of the catchment. Such morphology is similar for all the torrents of the catchment. Figure 4 presents cross sections of the Ravoire bed at various elevations. The first one (a) corresponds to the area immediately located under the main glacial bench, where near events of debris flow have been triggered. The torrent bed enlargement is due to the successive debris flow events of the 1970-80s. The present bed level is $15-20 \mathrm{~m}$ lower than before the events. At this elevation, the left bank is very abrupt and some slope movements could be activated. The profile (b) corresponds to the torrent morphology below. The difference with the (a) section is that the right slope is gentler due to the bank sapping during the 1981 event. In the cross-section (c), the torrent is much embanked. From the (d) section slopes are gentler still with the confluence with the Isère torrent. For all torrents, from stretch (a) to (d), destabilised trees, rocks and masses and bank instabilities testify to the geodynamical activation.

\section{Land use change above debris flow source areas}

\subsection{Chronology}

In the Savoie region, the 1960-70 decade was characterized by a great economical conversion due to the ski practice revolution. Between 1961 and 


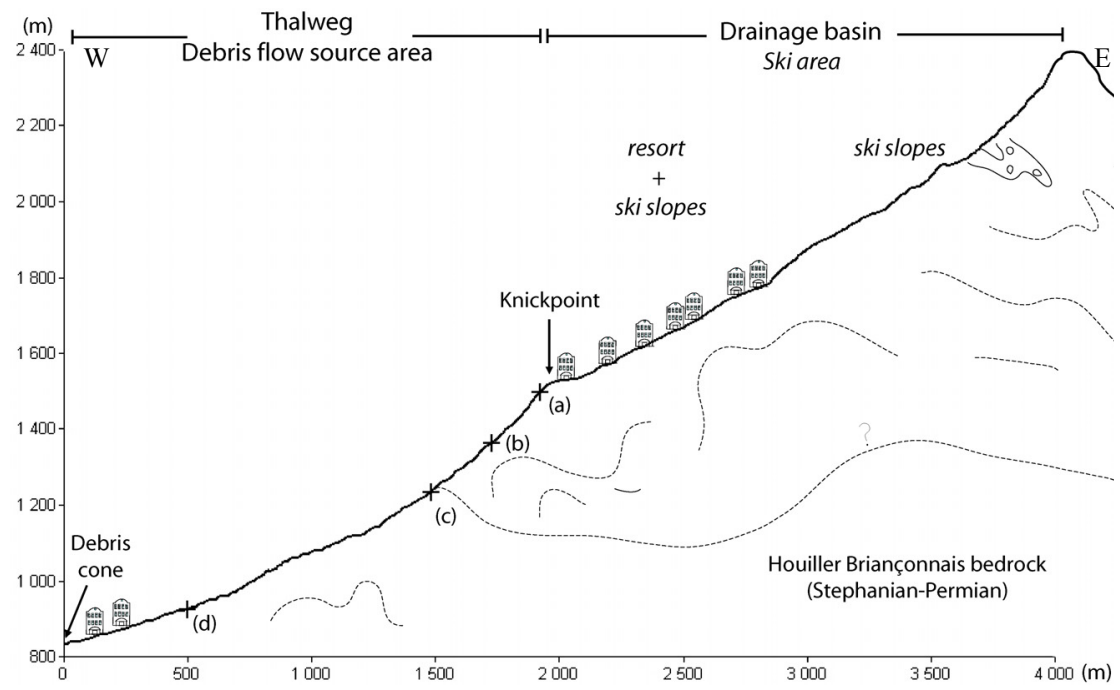

Figure 3: Longitudinal profile of la Ravoire catchment (from DEM) and location of the Arc 1600 resort.

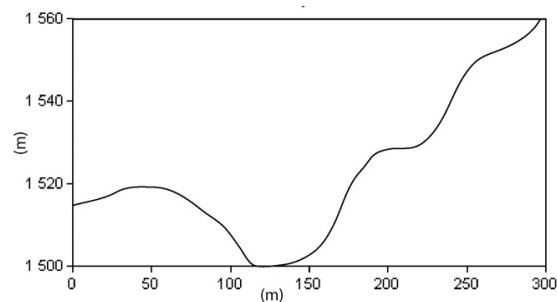

(a)

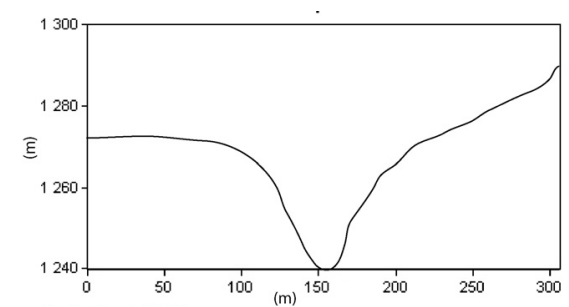

(c)

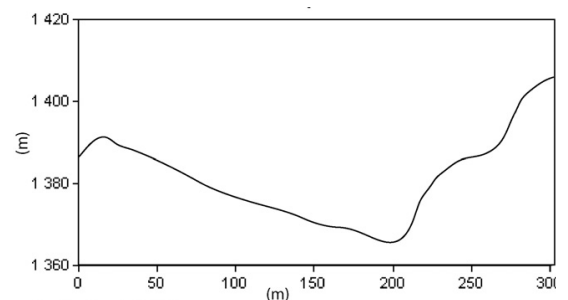

(b)

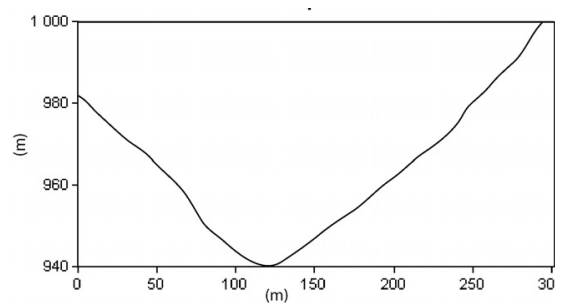

(d)

Figure 4: Cross sections (NE-SW) of la Ravoire torrent bed at various elevations (from DEM). 
1968 the northern part of the catchment was exploited with chairlifts (table 1). Then, the catchment was a virgin site only dedicated to pasture activity. Thus, the building of the first winter sport resort, Arc 1600 (fig. 1), began in 1968. Since 1973 buildings and amenities have been expanded to the south of the catchment with the creation of the Arc 1800 resort. In the 1990s construction and earth works were carried on southwards. We can also observe that works in the Les Arcs site are still in progress, with new building construction and ski run arrangements.

Table 1: $\quad$ Main dates of chronology for the buildings at Les Arcs.

\begin{tabular}{|c|c|c|}
\hline Dates & Buildings & Position \\
\hline $1961-1968$ & Courbaton chairlifts & \multirow{4}{*}{ North } \\
\hline $1966-1968$ & Access road to Arc 1600 & \\
\hline 1968 & Arc 1600 & \\
\hline $1968-1973$ & Access road to Arc 1800 & \\
\hline 1973 & Arc 1800 & \multirow{5}{*}{ South } \\
\hline 1978 & Arc 1800 - Villards village & \\
\hline 1984 & Arc 1800 - Charmettoger village & \\
\hline$?$ & Arc 1800 - Chantel village & \\
\hline 2008 & Works still in progress & \\
\hline
\end{tabular}

\subsection{Changes in land use}

The development of the winter sport resorts and of the ski area induced many changes to the catchment. These changes and their effects have been identified and analysed [18]. The main perturbations are summarized table 2.

Table 2: $\quad$ Main impacts of land management on the ski area.

\begin{tabular}{lccccc}
\hline $\begin{array}{c}\text { Management } \\
\text { types }\end{array}$ & Runoff & $\begin{array}{c}\text { Water } \\
\text { rerouting \& } \\
\text { concentrating }\end{array}$ & $\begin{array}{c}\text { Vegetation } \\
\text { decrease }\end{array}$ & Erosion & $\begin{array}{c}\text { Slope } \\
\text { instability }\end{array}$ \\
\hline $\begin{array}{l}\text { Deforestation } \\
\text { Impervious }\end{array}$ & $\mathrm{X}$ & $\mathrm{X}$ & $\mathrm{X}$ & $\mathrm{X}$ & $\mathrm{X}$ \\
areas & $\mathrm{X}$ & $\mathrm{X}$ & $\mathrm{X}$ & $\mathrm{X}$ & $\mathrm{X}$ \\
Roads & $\mathrm{X}$ & $\mathrm{X}$ & & $\mathrm{X}$ & $\mathrm{X}$ \\
Ski runs & $\mathrm{X}$ & & $\mathrm{X}$ & $\mathrm{X}$ \\
Irrigation & $\mathrm{X}$ & $\mathrm{X}$ & $\mathrm{X}$ & $\mathrm{X}$ & $\mathrm{X}$ \\
(golf) & & & & & \\
Artificial snow & $\mathrm{X}$ & & & $\mathrm{X}$ \\
\hline
\end{tabular}

\subsubsection{Impacts on runoff production}

This table shows that land use changes in a winter sport resort play a major role, mainly on runoff and erosion processes. Runoff is principally due to impervious area development, such as roofs, car parks, roads and ski runs, which are compacted surfaces inducing an important infiltration reduction [14, 19]. 
Deforestation for roads, buildings and ski slopes acts for runoff production in reducing interception by leaves and absorption by roots. Moreover, the modifications of watershed limits induced by grading works emphasized the hydrological imbalance. Finally, artificial snow production in winter and spring could be responsible for a modification of the global water balance of catchments because the notable quantity of water used for the supply of snow is generally derived from another catchment. It is noteworthy that this quantity of water smelts with some delay at spring during the high-water-flow period.

\subsubsection{Impacts on erosion processes}

First of all, the disappearance of the vegetal cover increases the impact of rainfall [20]. Furthermore, processes of erosion are mainly emphasized during the earth works period. Grading activity (cut and fill) is responsible for a massive production of spoil earth materials. Moreover, some materials are frequently pushed to torrent beds after such works. Such a practice is at the origin of the triggering of the first Ravoire debris flow event in 1970. However, 40 years later, similar practices have been observed during recent works. The man-caused runoff increases the superficial waters action on soils because of the phenomena of rerouting and concentrating in some areas, along roads ramps, ski runs, and more generally because of the increase of the torrent water flow.

\subsubsection{Impacts on slope stability}

Slope instabilities are frequent in a morphological context, such as the one at Les Arcs. However, they could be directly enhanced from construction and deforestation because of the decrease of root density [21,22]. Road construction on hillslopes inevitably decreases the site stability in the following ways: adding weight to the embankment fill, steepening the slope on both cut and fill surfaces, removing the support of the cutslope and rerouting and concentrating road drainage water [15]. Slope stability can be affected by residential development because of removal of support by excavation, mechanical overloading by fill placement, the concentration of water on the site or the introduction of additional water [15]. Finally, erosion processes represent another factor of instabilities, particularly in banks scouring.

\subsection{Worsening effects of land management above debris flow source areas}

In the Les Arcs catchment, the localisation of the ski area and resorts plays a major role on hazard intensification. As it is exposed as shown in figures 1 and 3 , because of the drainage basin configuration, massive land use changes are concentrated on the upper slopes in the reception basin, above the thalweg of torrents. Depending on the considered catchment, the reception basin surface could represent $52 \%$ (Ravoire) to $74 \%$ (Preissaz) of the total watershed surface. In all cases, impervious areas and ski runs represent more than $20 \%$ of reception basin surfaces. Spoil materials from grading activities above are carried to the thalweg by drainage water inducing erosion. During rain events, water is running from ski slopes and from impervious areas, rather than infiltrates, and then it is 


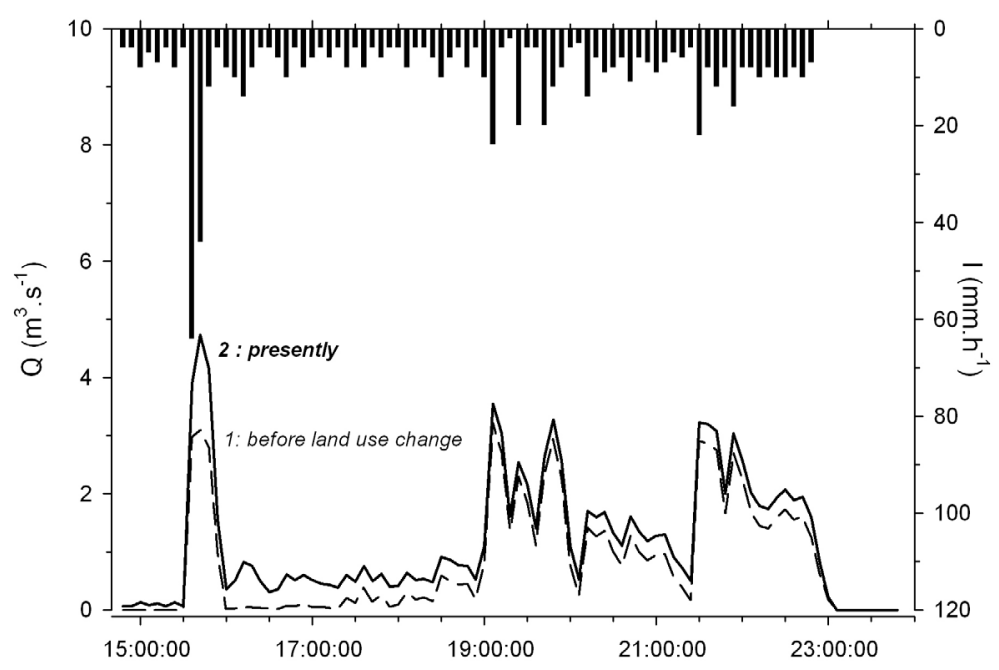

Figure 5: Ravoire torrent calculated hyetograph at the outfall of the resort above source areas depending on land use.

concentrated down to the urbanized area in the torrent with an increased discharge just above debris flow source areas. Consequences can be erosion, slope instabilities and the mobilisation of bank materials. A hydrological modelling approach has allowed underlining of the role of the land use change on the torrent flows. Simulations have been conducted with a distributed model [14] created in the PCRaster language [23]. Figure 5 represents the response of the La Ravoire torrent during a decennial rainfall depending on the land use, before the ski resort construction and presently. The hyetograph is calculated at the outfall of the drainage basin.

The variation in intensity between the two discharge curves shows that the catchment response to a rainfall event solicitation is significant considering the land use factor. The mean discharge calculated during the decennial rainfall was $0,9 \mathrm{~m}^{3} \cdot \mathrm{s}^{-1}$ before the resort construction, but had risen to $1,3 \mathrm{~m}^{3} \cdot \mathrm{s}^{-1}$ in the $2000 \mathrm{~s}$. This represents an increase of $44 \%$. However, the effect of land use change is particularly significant on the peak flow value estimated at $+52 \%$ at the exit of the resort above the debris flow source areas. At the annual scale, the increase of the discharge is notable too. Considering the mean annual regime of precipitation at Bourg-St-Maurice, the water balance model has calculated an increase equivalent to $24 \%$ of the mean annual discharge at the outfall of the catchment, (with a peak of $26 \%$ during the high water flow period) induced by an increase of $7,5 \%$ of the runoff. 


\section{Conclusion}

In the early 1970s, the debris flow occurrence in the Les Arcs site has revealed an active geodynamic context. At the same time, important modifications were induced on the upper slopes by construction of two winter sport resorts and their ski area. Our analysis supports the fact that the natural susceptibility of the catchment to debris flow hazards due to geological, morphological and climatic predispositions has been enhanced by human activities and the effects of land use changes. The conversion of the traditional land use to a use dedicated to tourist activities has led to a water imbalance attributed to the increase of the runoff induced by four phenomena: deforestation, soils properties degradation, impervious surfaces construction and water transfers. Erosion processes and slope instabilities have resulted from this change too: spoils production, runoff and torrent flow increase. These negative effects are damaging, considering that perturbations are concentrated in the reception basin above the debris flow source areas. Indeed, erosion on the upper slopes produces materials liable to be brought to the torrent bed and to favour erosion processes. Moreover, the significant increase of the torrent discharge, and particularly the peak flow underlined by the hydrological model, advantages bank erosion and bed scouring. Thus, materials and local landslides resulting from bank erosion processes are susceptible to feed debris flow events. This analysis confirms the hypothesis of a space-time concordance between land use change in the upper slopes and debris flow triggering downstream following a north-south axis.

\section{References}

[1] Varnes D.J.: Slope Movement/Types and Processes. Landslides Analysis and Control, Special report 176, Schuster RL, Krizek R.J. editors, National Academy of Sciences, pp.11-33. (1978)

[2] Hutchinson J.N., General report: Morphological and geotechnical parameters of landslides in relation to geology and hydrogeology. Proc. of the $5^{\text {th }}$ Int. Symp. On Landslides, ed. Bonnard C., Balkema, 1, pp.3-35, 1988.

[3] Meunier M., Les progrès de la connaissance et les méthodes d'étude des phénomènes torrentiels, La Houille Blanche, 3, pp.25-31, 1994.

[4] Cruden D.M. \& Varnes D.J., Landslides types and processes. Turner A.K. \& Schuster R.L. (eds), Landslides, investigation and mitigation. National Academy Press, Washington, pp.36-75, 1996.

[5] Hungr O., Evans S.G., Bovis M.J. \& Hutchinson J.N., A review of the Classification of Landslides of Flow Type. Environmental \& Engineering Geoscience, 7(3), pp.221-238, 2001.

[6] Takahashi T., Debris flows. IAHR/AIRH Monograph, Balkema, 165p. 1991.

[7] Coussot P., Rhéologie des boues et laves torrentielles. Etude des dispersions et suspensions concentrées. Série montagne 5, études du CEMAGREF, 413p., 1993. 
[8] Cojean R. \& Staub I., Mécanismes d'initiation des laves torrentielles dans les Alpes françaises, Proc. $8^{\text {th }}$ Conf. of AIGI, Vancouver, Canada, Sept. 2125, Balkema, (3) pp.2075-2082, 1998.

[9] Caine N., Rainfall intensity-duration control of shallow landslides and debris flows, Geografiska Annaler., 62 A, p.23-27, 1980.

[10] Govi M., Mortara G. \& Sorzana P.F., Eventi idrologici e frane, Geologia Applicata et Idrologeologia, Bari, 10(2), pp.359-375, 1985.

[11] Zimmermann M. \& Haeberli W., Climatic Change and Debris Flow Activity in High-Mountain Areas. A Case Study in the Swiss Alps. Greenhouse-Impact on Cold-Climate Ecosystems and Landscapes, Catena Sup. (22) pp. 59-72, 1992.

[12] Rebetez M., Lugon R. \& Baeriswyl P.A., Climatic change and debris flows in high mountain regions: the case study of the Ritigraben torrent. Clim. Change, 36, pp.371-389, 1997.

[13] Jomelli V., Pech V.P., Chochillon C. \& Brunstein D., Geomorphic variations of debris flows and recent climatic change in the French Alps, Climatic Change (64) pp.77-102, 2004.

[14] Koscielny M., Impacts des aménagements sur l'évolution géodynamique des versants. Application au site des Arcs. PhD thesis, UMLV-ENSMP, 350p., 2006.

[15] Sidle R.C., Pearce A.J. \& O’Loughlin C.L., Hillslope Stability and Land Use, Water resources Monogram, Vol 11, American Geophysical Union, Washington, D.C., 140 p., 1985.

[16] Slosson J.E. \& Larson R.A., Slope Failures in Southern California: Rainfall Threshold, Prediction, and Human Causes. Env. \& Eng. Geosc. 1(4), pp.393-401, 1995.

[17] Mougin P., Les torrents de la Savoie, Grands Etablissements de l'Imprimerie Générale, Grenoble, 1251p., 1914.

[18] Koscielny M., Impacts des aménagements en montagne sur les processus hydrologiques et l'évolution géodynamique des versants (Les Arcs, Savoie, France), Bull. of Eng. Geol. and Env. (in press).

[19] Ardvisson J., Subsoil compaction caused by heavy sugarbeet harvesters in southern Sweden. I. Soil physical properties and crop yield in six field experiments. Soil \& Tillage Research 60 pp.67-78, 2001.

[20] Sternberg H.O., Enchentes e movimentos coletivos do solo no vale do Paraiba, em dezembro de 1948: influêcia da explotaçao destrutiva da terra. Rev Brasil Geog, 11 (2) pp.223-261, 1949.

[21] Endo T. \& Tsuruta T. On the effect of tree's roots upon the shearing strength of soil. Annual report of the Hokkaido Branch Forest Experiment Station, Sapporo, pp.167-182, 1969.

[22] Prandini L., Guidicini G., Bottura J.A., Ponçano W.L. \& Santos A.R., Behaviour of the vegetation in slope stability: a critical review. Bull Engin Geol, Krefeld, 16 pp.51-55, 1977.

[23] Karssenberg D., Wesseling C.G. \& Van Deursen W.P.A., PCRaster Version 2 Manual. Utrecht Univ, Netherlands, 380p, 1996. 